\title{
Taxonomy of Indigenous Construction Firms in South-South Nigeria
}

\author{
"Chukwuemeka Patrick Ogbu' and Christian Fidelis Asuquo²
}

Published online: 31 December 2019

To cite this article: Chukwuemeka Patrick Ogbu and Christian Fidelis Asuquo (2019). Taxonomy of indigenous construction firms in South-South Nigeria. Journal of Construction in Developing Countries, 24(2): 189-206. https://doi.org/10.21315/ jcdc2019.24.2.9.

To link to this article: https://doi.org/10.21315/jcdc2019.24.2.9

\begin{abstract}
Contractors are generally grouped as small, medium or large, or, indigenous or foreign. An unsupervised statistically derived grouping of indigenous contractors hardly exists. Such a grouping is critical to policy formation for indigenous construction firms (ICFs) development in Nigeria. The objectives of this study were: (1) to group ICFs based on their characteristics and (2) to identify the significant characteristics that discriminate among the groups of ICFs. The ICFs $(n=575)$ studied were obtained from sample frames retrieved from construction industry professional bodies, the Bureau of Public Procurement (BPP) and internet sources. The results of the study were based on the demographic data of 428 of the ICFs that returned acceptably filled copies of the study questionnaire. Using cluster analysis, 97.9\% of the ICFs were correctly classified into three groups based on their characteristics. Discriminant analysis revealed that two functions (experience and marketing) discriminate among the three groups. The two functions are particularly distinguishable by high loadings in firm experience and firm registration with client bodies. This study demonstrates that ICFs can be classified using other parameters than those traditionally in use. Future ICF development programmes could be tailored along the lines of the three distinct groups discovered in this study.
\end{abstract}

Keywords: Cluster analysis, Contractor development, Discriminant analysis, Indigenous construction firms

\section{INTRODUCTION}

Indigenous construction firms (ICFs) in Nigeria are not fully understood. Until recently, very little was known about how Nigerian contractors could be grouped. Besides grouping them into foreign/expatriate and indigenous firms (national, regional or local) (Idoro, 2011) on the basis of geographical reach of operations, a rather common practice was to base the classification of contractors on their annual turnovers alone or some set of few criteria (Adeyemi, Oladapo and Akindele, 2005; Akintoye, Mclntosh and Fitzgerald, 2000). These narrowly-focussed classifications deny stakeholders of useful insights into other equally important metrics of organisational effectiveness and developmental statuses of ICFs. Again, as noted by Pizzoli and Palmegiani (2007), a particular weakness of such categorisation is that it is not statistically derived and so it could mask other significant variables accounting for variations in the taxonomy of the firms, which makes it difficult to understand individual differences. The categorisation of construction companies in Nigeria into Categories $\mathrm{A}$ to $\mathrm{E}$ on the basis of equipment ownership, personnel, number

\footnotetext{
'Department of Quantity Surveying, University of Benin, Benin City, NIGERIA 2Department of Quantity Surveying, University of Uyo, Akwa Ibom, NIGERIA

"Corresponding author: mcmekusa@yahoo.com
} 
of completed jobs and turnover (Bureau of Public Procurement [BPP], 2015) suffers this set back. Obviously, the number of groups and the grouping criteria used were not obtained from the sources of variance within the set of contractor qualification data. Even for the purposes of contractor pre-qualification, the criteria leave much questions unanswered regarding the capacity of the contractors. Additionally, it is clear the categorisation is not intended for the purposes of understanding the differences between the firms and for tailoring contractor development programmes, and, therefore, do not cater for ICFs exclusively.

Inadvertently, studies related to contractors have tended to categorise them alone the lines used by government agencies especially, into large, medium and small-sized firms (Dulaimi and Shan, 2002; Kartam, Flood and Koushki, 2000; Odeyinka, 2000). Findings in such studies could be confounded by the existence of other discriminating traits among the firms that do not correlate with the chosen few criteria. For example, a study on the project performance of various contractors in which data was segregated into large, medium and small-sized firms may ignore the effect of capacity of site personnel, supposing that is a significant discriminant among the firms. Thus, a classification of ICFs which statistically emanate from most of the firms' characteristics will be superior in accurately placing each firm within its rightful category.

Although the importance of ICFs is widely acknowledged, their numerous problems, including short-term orientation, reliance on unqualified personnel and lack of focus, are equally recognised (Ofori, 2000). Consequently, there have been various calls to improve the capacity of indigenous contractors in the execution of projects within developing countries (Adams, 1997; Dlungwana and Rwelamila, 2004; Ofori, 2000). These calls are justified by the need to attain self-reliance in construction and break the dominance of foreign contractors whose activities have not produced the much-desired technology transfer within local firms. While only insignificant deliberate efforts have been made to shore up the performance of the ICFs in countries such as Nigeria, a critical requirement for tailoring contractor development programmes will be the development of taxonomy of the ICFs.

A robust approach to contractor classification that accommodates attributes of contractors other than those expressly needed for prequalification is germane to understanding developing countries' indigenous contractors. As an example, in most cases, extant firm classification methods give inadequate regards to the attributes of the owners of the firms. They rather concentrate on the attributes of the firms themselves. Conceptually, firms are different from their owners. In the Nigerian indigenous construction firm sense, the attributes of the firm owner can produce a confounding effect on the expected performance of a firm. The continued under performance of ICFs in Nigeria justifies the expansion of the variables considered to affect their performance, and, therefore, classification. A pertinent factor to consider is the social status of the firm owners, which according to Hollingshead (1975) includes their education, occupation, sex and marital status. A firm possessing good resources in terms of manpower, equipment and finance may still under-perform at firm and site levels as a result of the quality of its leadership. This is often unaccounted for by existing construction firm categorisation methods, which emphasise employees' qualifications and experience rather than the firm owner's. In the small and medium-sized (SME) firm context generally, the qualifications and experience of the firm owner matter more to the firm's survival (Madhoushi and Ghaedi, 2013). 
ICFs being mostly SME sole proprietorships (Ogbu, 2018), the attributes of the firm owners should concern the clients since this will ultimately bear on project delivery. Thus, it is vital to reach beyond mere firm variables and include firm owner variables when classifying indigenous contractors for development purposes. Mostly, construction firm development training workshops will focus on the firm owners. When trained, the firm owners will then undertake an organisation-wide implementation of the outcomes of such trainings. Firm owner attributes have, therefore, been included in the variables used in classifying the firms in this study. A robust classification of indigenous contractors such as the one proposed in this study will provide a basis for challenging existing contractor classification systems, especially, those in use by government agencies like the BPP in Nigeria. Likewise, the Tenders Boards of procuring entities as well as construction consultants will be better informed on the criteria to use in choosing contractors in order to meet the clients' objectives.

\section{Variables for Classifying Indigenous Construction Firms}

Variables used in the classification of firms must be tailored towards the purpose of the classification (Miller and Roth, 1994). Some classifications of contractors use measures that inform on the contractors' project performance capacities including personnel, equipment ownership, turnover, experience, amongst others (BPP, 2015). Table 1 shows that the two predominant objectives for which contractor categorisation is carried out are (1) for grading contractors in the order of the monetary values of the projects that they could be awarded by the government (2) for the prequalification of contractors. The classification variables were, therefore, tailored to achieve the two goals. However, Ofori (1991) advocated the country specificity of contractor development programmes, which necessitates the adoption of a classification system that is locally derived based on the needs of the firms.

Table 1. Classification of Contractors and Criteria Used

\begin{tabular}{llll}
\hline Author & Purpose & Criteria & Classification \\
\hline BPP (2015) & $\begin{array}{l}\text { National grading } \\
\text { of contractors }\end{array}$ & $\begin{array}{l}\text { Personnel, equipment } \\
\text { ownership, turnover and } \\
\text { experience }\end{array}$ & $\begin{array}{l}\text { Classes: A, B, C, } \\
\text { D and E }\end{array}$ \\
Holt (1996) & Prequalification & $\begin{array}{l}\text { Organisation, financial, } \\
\text { management, experience } \\
\text { and performance criteria }\end{array}$ & \\
$\begin{array}{l}\text { Odeyinka (2000); } \\
\begin{array}{l}\text { Drew and } \\
\text { Skitmore (1990) }\end{array}\end{array}$ & $\begin{array}{l}\text { Size/ } \\
\text { prequalification }\end{array}$ & $\begin{array}{l}\text { Worth of contract/financial } \\
\text { capacity }\end{array}$ & $\begin{array}{l}\text { Large, medium } \\
\text { and small }\end{array}$ \\
\hline
\end{tabular}


Table 1. (continued)

\begin{tabular}{|c|c|c|c|}
\hline Author & Purpose & Criteria & Classification \\
\hline \multirow[t]{4}{*}{$\begin{array}{l}\text { Hatush and } \\
\text { Skitmore (1997) }\end{array}$} & \multirow[t]{4}{*}{ Prequalification } & $\begin{array}{l}\text { Management safety, } \\
\text { accountability, experience } \\
\text { modification rate, length } \\
\text { of time in business, safety } \\
\text { performance, occupational } \\
\text { housing rate, owner/ } \\
\text { contractor relationship, credit } \\
\text { rating, financial stability, } \\
\text { technical personnel and } \\
\text { plant and equipment }\end{array}$ & \multirow[t]{4}{*}{$\begin{array}{l}\text { Desirable and } \\
\text { undesirable } \\
\text { contractors }\end{array}$} \\
\hline & & $\begin{array}{l}\text { Occupational housing } \\
\text { rate and management } \\
\text { knowledge }\end{array}$ & \\
\hline & & $\begin{array}{l}\text { Past performance and } \\
\text { project management } \\
\text { organisation }\end{array}$ & \\
\hline & & Bank arrangements & \\
\hline \multirow[t]{9}{*}{ Almutairi (2017) } & \multirow{9}{*}{$\begin{array}{l}\text { National grading } \\
\text { of contractors }\end{array}$} & Technical Criteria & \multirow[t]{9}{*}{ Grades 1 to 5} \\
\hline & & $\begin{array}{l}\text { Personnel: Principals, } \\
\text { engineers and technicians }\end{array}$ & \\
\hline & & $\begin{array}{l}\text { Equipment (construction } \\
\text { works only) }\end{array}$ & \\
\hline & & $\begin{array}{l}\text { Projects: Project value, } \\
\text { monthly load, yearly load, } \\
\text { high value projects and } \\
\text { continuity }\end{array}$ & \\
\hline & & $\begin{array}{l}\text { Reports: Site visits, head office } \\
\text { visit and client surveys }\end{array}$ & \\
\hline & & Financial Criteria & \\
\hline & & $\begin{array}{l}\text { Balance sheet: Total asset, } \\
\text { working capital and net worth }\end{array}$ & \\
\hline & & $\begin{array}{l}\text { Profit and loss: Total revenue, } \\
\text { contracting revenue, net } \\
\text { income and net cash income }\end{array}$ & \\
\hline & & $\begin{array}{l}\text { Financial ratios: Leverage, } \\
\text { profitability and efficiency }\end{array}$ & \\
\hline Ogbu (2017) & $\begin{array}{l}\text { Marketing } \\
\text { strategies }\end{array}$ & Revenue to employee ratio & $\begin{array}{l}\text { Low, average } \\
\text { and high } \\
\text { performers }\end{array}$ \\
\hline
\end{tabular}


In this study, the choice of grouping variables was guided by the need to group ICFs in a way that aids the implementation of contractor development programmes. For example, the previous classifications of contractors highlighted above did not use the location of the firm's headquarters in their classification. Understandably, the intentions were not to know whether the characteristics of contractors in a city tend to be alike or not. Contrariwise, in this study, such variables are included to examine whether the groups of ICFs can be spatially understood. Likewise, the earlier grouping variables did not include measures to check the entrepreneurial capability of the firms. McCutcheon (2001) for instance, canvassed that contractor development programmes should pay as much attention to character as to technical matters. Ofori (1991) proposed that contractor development programmes for ICFs should cover the teaching of entrepreneurship subjects such as corporate strategy, administration and financial management. Kubayi (2014) highlighted that technical, administrative, contractual, managerial and entrepreneurial were among the capabilities sought to be instilled in contractors undergoing the Vuk'uphile Learnership Programme in the Eastern Cape Department of Roads and Public Works, South Africa. It is essential, therefore, that such measures are reflected in any attempts to classify contractors for training purposes. Table 2 shows the variables used in grouping contractors in this study. Measures covering most of the areas of concern in contractor development programmes for the ICFs were covered. The variables were grouped into (1) firm owner characteristics and (2) firm characteristics. Since, mostly, ICFs are owner-managed, the attributes of the owner play prominent roles in the administration and ultimately, the performance of the firms. This incentivises the search for the social status attributes of indigenous construction firm owners that are relevant to the classification of their firms such as gender, marital status and others.

Kalleberg and Leicht (1991) investigated the differences in the success of businesses led by men and women and found no differences. Their investigation, however, was focused on firms in the food and drink, computers and health industries. Construction is clearly a male-dominated industry (Adeyemi et al., 2006). It is, therefore, possible that the socio-cultural status of women will affect their construction firm leadership effectiveness (especially in the African context), which will place such firms in a separate category from those led by men (Birley, 1987). In a Nigerian study, Woldie and Adersua (2004) observed that the greatest challenge of Nigerian businesswomen is being taken seriously by their male counterparts. Loosemore and Waters (2004) found differences in the sources and levels of stress between male and female construction personnel, which highlighted the men's continued dominance of the construction industry. Dainty, Bagilhole and Neale, (2000) advocated that conscious efforts to engage women in the construction industry should be stopped until the discriminatory and exclusionary behaviour against women in the industry ceases. Construction management literature is yet to clarify the differences (if any) between construction firms led by men and those led by women to ascertain whether they should be differently classified given the above realities.

Marriage is thought to make workers more productive. Married men are more likely to be promoted in jobs and they receive higher performance rating than single men (Korenman and Neumark, 1991). Choudhry, Fang and Lingard (2009) noted that marital status can affect the safety behaviour of construction personnel and safety is an important project performance metric. Wang et al. (2016) observed that marital status could affect a project manager's propensity to perceive risks. 
Besides, married firm owners often have family members assisting or working full time in their firms, which creates a very different scenario from the firms of those who lack such helps (Wong, 1986). A construction firm owner's spouse may help him/ her to get jobs for the firm or raise badly needed funds to keep a project running, a leverage which is unavailable to construction firm owners not having spouses. Such instances go unaccounted for in most studies related to construction firms and are generally ignored in existing construction firm classification methods.

Table 2. Variables for Classifying ICFs

\begin{tabular}{|c|c|c|c|}
\hline Characteristic & Code & Measurement & Scale \\
\hline \multicolumn{4}{|l|}{ Firm Owner } \\
\hline Age of owner & $\mathrm{V} 1$ & Actual age at last birthday & Interval \\
\hline Education of owner & V2 & $\begin{array}{l}\text { High = } 2 \text { (for Master of Science [MSc] } \\
\text { holders and above); Intermediate = } 1 \text { (for } \\
\text { Higher National Diploma [HND]/Bachelor of } \\
\text { Science [BSC] holders); Otherwise }=0\end{array}$ & Nomina \\
\hline Marital status & V3 & $\begin{array}{l}\text { Dummy variable: } 4=\text { Unmarried; } 3= \\
\text { Married; } 2=\text { Widowed; } 1 \text { = Divorced; } \\
\text { Otherwise }=0\end{array}$ & Nomina \\
\hline $\begin{array}{l}\text { Professional } \\
\text { qualification }\end{array}$ & V4 & $\begin{array}{l}\text { Nigerian Institute of Quantity Surveyors } \\
\text { (NIQS) = 1; Nigerian Institute of Architects } \\
\text { (NIA) = 2; Nigerian Institute of Building } \\
\text { (NIOB) = 3; Nigerian Society of Engineers } \\
\text { (NSE) = 4; None =0 }\end{array}$ & Nomina \\
\hline $\begin{array}{l}\text { Construction industry } \\
\text { work experience }\end{array}$ & V5 & $\begin{array}{l}\text { Number of years of work in the construction } \\
\text { industry }\end{array}$ & Interval \\
\hline Gender & V6 & Male $=1$; Otherwise $=0$ & Nomina \\
\hline $\begin{array}{l}\text { Previous self- } \\
\text { employment }\end{array}$ & V7 & Yes $=1 ; \mathrm{No}=0$ & Nomina \\
\hline Ethnicity of owner & V8 & $\begin{array}{l}\text { If the owner of firm is from the South-South } \\
=1 \text {; Otherwise }=0\end{array}$ & Nomina \\
\hline $\begin{array}{l}\text { Ownership of other } \\
\text { business(es) }\end{array}$ & V9 & Yes $=1 ; \mathrm{No}=0$ & Nomina \\
\hline $\begin{array}{l}\text { Chief executive officer } \\
\text { (CEO) duality }\end{array}$ & V10 & $\begin{array}{l}\text { If the owner of the firm is also the CEO = } 1 \text {; } \\
\text { Otherwise }=0\end{array}$ & Nomina \\
\hline \multicolumn{4}{|l|}{ Firm } \\
\hline Firm age & V11 & Actual age of business in years & Interval \\
\hline Firm size & $\vee 12$ & $\begin{array}{l}\text { Natural logarithm of a firm's permanent staff } \\
\text { in } 2014\end{array}$ & Ratio \\
\hline Technology use & $\vee 13$ & $\begin{array}{l}\text { Amount spent on information and } \\
\text { communications technology (ICT) per } \\
\text { month }\end{array}$ & Ratio \\
\hline
\end{tabular}


Table 2. (continued)

\begin{tabular}{|c|c|c|c|}
\hline Characteristic & Code & Measurement & Scale \\
\hline Firm location & V14 & $\begin{array}{l}\text { Dummy variable: If firm is located in the } \\
\text { state capital }=1 \text {; Otherwise }=0\end{array}$ & Nominal \\
\hline $\begin{array}{l}\text { Type of project of } \\
\text { specialisation }\end{array}$ & V15 & Civil/building construction $=1$; Otherwise $=0$ & Nominal \\
\hline Firm experience & V16 & $\begin{array}{l}\text { Score based on types of projects in which } \\
\text { the firm have participated }\end{array}$ & Nominal \\
\hline $\begin{array}{l}\text { Firm registration with } \\
\text { client bodies }\end{array}$ & V17 & $\begin{array}{l}\text { Number of organisations with which the firm } \\
\text { is registered }\end{array}$ & Ratio \\
\hline Annual turnover & V18 & $\begin{array}{l}\text { Gross income of the firm (in naira [NGN]) in } \\
\text { the last financial year }\end{array}$ & Ratio \\
\hline Group membership & V19 & $\begin{array}{l}\text { If the company is a member of a large } \\
\text { group of companies }=1 \text {; Otherwise = } 0\end{array}$ & Nominal \\
\hline $\begin{array}{l}\text { Founding condition/ } \\
\text { initial size }\end{array}$ & V20 & $\begin{array}{l}\text { Number of permanent staff at the start of } \\
\text { the company }\end{array}$ & Ratio \\
\hline $\begin{array}{l}\text { Organisational } \\
\text { structure }\end{array}$ & V21 & $\begin{array}{l}\text { Vertical organisational structure }=1 \\
\text { Horizontal organisational structure }=0\end{array}$ & Nominal \\
\hline $\begin{array}{l}\text { Level of firm } \\
\text { registration }\end{array}$ & V22 & $\begin{array}{l}\text { Class: } A=5 ; B=4 ; C=3 ; D=2 ; E=1 \\
\text { None }=0\end{array}$ & Nominal \\
\hline
\end{tabular}

\section{RESEARCH METHODOLOGY}

Two key questions were set for this study. The first question relates to how ICFs in South-South Nigeria (comprising Akwa Ibom, Bayelsa, Cross River, Delta, Edo and Rivers States) may be grouped for contractor development programme purposes. The second question is "What factors account for the grouping of the ICFs?". Patton (1990) succinctly expressed the view that research, like diplomacy, is the art of the possible. Wherever it is advantageous to do so, Amaratunga et al. (2002) argues that qualitative and quantitative approaches should be combined in built environment research. Thus, although the ontological position of this paper is solidly objectivist given that the groupings of ICFs are independent of our conceptions of it, a relativist epistemology was adopted in obtaining the variables studied from literature.

The respondent firms for this study were gotten from sample frames developed from the contacts of ICF staffs who are members of professional bodies namely: NIQS, NIA, NIOB and NSE. The leaders of these bodies in the states of interest were requested to assist the researchers by supplying the names and contacts of their members working in ICFs. Further names of firms were obtained from the database of the BPP and other internet-based sources. Increasing use of the internet by construction firms was reported by Gaith, Khalim and Ismail (2012), which makes this a veritable source for identifying ICFs in the research area. It was considered expedient that the sample for the study should cover a large number of firms so as make the grouping of the firms more generalisable. The number of respondents $(n=575)$ obtained from each sample frame is shown in Table 3. 428 acceptably filled copies of the questionnaire were used in the study (as shown in Table 4). 
The study questionnaire was partly hand-administered on the sample through the help of 18 trained research assistants and partly administered through emails. Amongst others, the questionnaire sought and obtained information on the variables listed in Table 2.

The technique of cluster analysis was used in grouping the firms in this study. The technique was used in previous construction studies by Holt (1996) for contractor prequalification, Dikmen, Birgonul and Budayan (2009) to identify possible strategic groups within the Turkish construction industry, Tran and Carmichael (2013) for classification of clients' payment practices. This study uses the technique to classify ICFs operating in South-South Nigeria. The firms were clustered using Statistical Package for Social Sciences (SPSS) Version 20 (IBM Corporation). The procedure used in Dikmen, Birgonul and Budayan (2009) was adapted and followed in this study. SPSS gives three approaches to clustering: hierarchical cluster, k-means cluster and two-step cluster analyses. The data for this study were subjected to analysis using each of the methods. This approach was adopted to compensate for the weaknesses of each of the cluster analysis techniques in order to arrive at an optimised solution.

Table 3. Sample Frames Obtained and Number of Respondents in Each

\begin{tabular}{lcccrccc}
\hline State & NIQS & NIA & NIOB & NSE & BPP & Internet & Total \\
\hline Akwa lbom & 16 & 14 & 15 & 17 & 12 & 28 & 102 \\
Bayelsa & 11 & 15 & 13 & 16 & 8 & 24 & 87 \\
Cross River & 12 & 12 & 17 & 19 & 11 & 19 & 90 \\
Delta & 16 & 19 & 14 & 24 & 21 & 21 & 115 \\
Edo & 21 & 23 & 11 & 9 & 13 & 16 & 93 \\
Rivers & 11 & 15 & 15 & 18 & 11 & 18 & 88 \\
Total & 87 & 98 & 85 & 103 & 76 & 126 & 575 \\
\hline
\end{tabular}

Table 4. Result of Questionnaire Administration

\begin{tabular}{|c|c|c|c|c|c|c|c|}
\hline \multirow{3}{*}{ State } & \multicolumn{7}{|c|}{ Questionnaire } \\
\hline & \multirow{2}{*}{ Administered } & \multicolumn{2}{|c|}{ Returned } & \multicolumn{2}{|c|}{ Used for the Study } & \multicolumn{2}{|c|}{ Discarded } \\
\hline & & No. & $\%$ & No. & $\%$ & No. & $\%$ \\
\hline Akwa lbom & 102 & 86 & 84.31 & 81 & 94.19 & 5 & 5.81 \\
\hline Bayelsa & 87 & 67 & 77.01 & 65 & 97.01 & 2 & 2.99 \\
\hline Cross River & 90 & 69 & 76.67 & 69 & 100.00 & - & - \\
\hline Delta & 115 & 85 & 73.91 & 84 & 98.82 & 1 & 1.18 \\
\hline Edo & 93 & 68 & 73.12 & 67 & 98.53 & 1 & 1.47 \\
\hline Rivers & 88 & 65 & 73.86 & 62 & 95.38 & 3 & 4.62 \\
\hline Total & 575 & 440 & 76.52 & 428 & 97.27 & 12 & 2.73 \\
\hline
\end{tabular}




\section{RESULTS}

First, the data for the study was tested for multicollinearity. The first results of the Pearson correlations showed strong correlations between firm size, firm age and construction industry work experience. The correlations remained strong even after logarithm and inverse transformations of the variables. As a result, firm age and size were removed from the analysis. Table 5 shows that no consequential multicollinearity problems persist in the data used in the analysis. In order to check the effect of scale differences the data were standardised before being subjected to the analysis. Since most of the data were at nominal and ordinal levels, hierarchical cluster analysis was carried out using Manhattan (city block) distance. The resulting dendrogram suggested a two or three group solution. A two-step cluster analysis was subsequently carried out to determine the number of clusters, which yielded two clusters. Two-step cluster analysis automatically determines the number of clusters. However, it requires that all variables are independent, continuous and normally distributed and that categorical variables have multinomial distribution (Dikmen, Birgonul and Budayan, 2009). It is difficult to meet these requirements in practice. In this study, the two-step cluster analysis gave a two-cluster solution, both using the Schwarz's Bayesian Criterion (BIC) and Akaike's Information Criterion (AIC). Following the results of the hierarchical and two-step cluster analyses, $K$-means cluster analysis was conducted for two and three clusters. For the 2-clusters solution, the distance between the centres of the clusters was found to be 2.780. In the 3-cluster solution, the distance became 2.686 (between Clusters 1 and 2), 3.245 (between Clusters 1 and 3) and 4.147 (between Clusters 2 and 3). The result implies that there is a possibility of losing some vital data in the 2-cluster solution. Consequently, the number of clusters was determined as three. The first, second and third groups have 172,213 and 37 firms respectively.

Multiple discriminant analysis was carried out to investigate how the three groups differ. Discriminant analysis helps to determine how well the groups differ and the variables that are responsible for the differences. Although the Box's $M$ test was significant $(F=2.502, p<0.000)$, the analysis was considered valid. Box's $M$ tests the null hypothesis that the covariance matrices do not differ between groups formed by the dependent variables. However, this test is less reliable when the sample is large (Bian, n.d.). The log determinants of the groups were -5.19 (Group 1), -8.684 (Group 2) and -11.37 (Group 3). The closeness of these figures to one another gave the assurance that the covariance matrices did not differ largely between the groups. Two functions were gotten from the analysis. Both were significant determinants $\left(\lambda=0.094, R^{2}=74.5 \%, p<0.05\right.$ for Function 1 and $\lambda=0.371, R^{2}=62.9 \%, p<0.05$ for Function 2) of a firm's group. The structure matrix of the functions shows that technology use, construction industry work experience and age of owner were important determinants of the firms' groups. Table 6 further suggests that firm experience and firm registration with client bodies were useful variables for understanding the groupings. While the former loaded highly in Function 1, the latter loaded highly in Function 2. Functions 1 and 2 have been christened experience and marketing functions respectively. Variables with loading of $\geq 0.30$ were considered to be significant (Bian, n. d). 


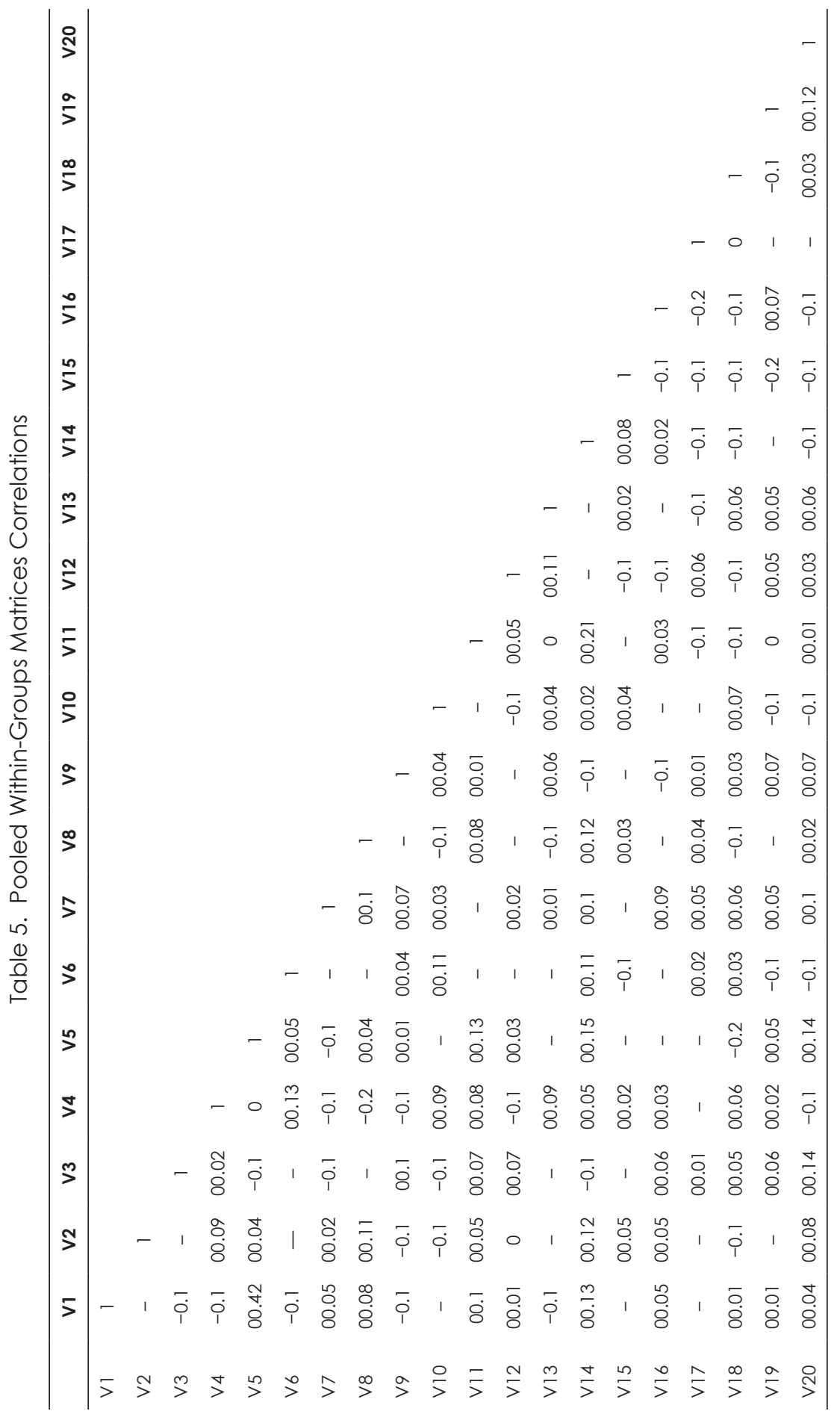


Table 6. Structure Matrix and Group Centroids

\begin{tabular}{|c|c|c|}
\hline \multirow{2}{*}{ Structure Matrix } & \multicolumn{2}{|c|}{ Function } \\
\hline & 1 & 2 \\
\hline \multicolumn{3}{|l|}{ Variables } \\
\hline Technology use & 0.743 & -0.549 \\
\hline Construction industry work experience & 0.520 & 0.405 \\
\hline Age of owner & 0.451 & 0.419 \\
\hline Firm experience & 0.327 & 0.207 \\
\hline Marital status & -0.191 & -0.101 \\
\hline Previous self-employment & 0.135 & -0.08 \\
\hline Ethnicity of owner & -0.063 & -0.016 \\
\hline Firm registration with client bodies & 0.132 & 0.327 \\
\hline Level of firm registration & 0.029 & -0.206 \\
\hline Ownership of other business(es) & 0.065 & 0.141 \\
\hline Founding condition/initial size & 0.105 & 0.127 \\
\hline Professional qualification & -0.011 & 0.118 \\
\hline Firm location & 0.012 & -0.094 \\
\hline CEO duality & -0.063 & -0.092 \\
\hline Organisational structure & 0.057 & 0.087 \\
\hline Gender & 0.035 & 0.065 \\
\hline Education of owner & 0.052 & -0.055 \\
\hline Annual turnover & 0.002 & 0.049 \\
\hline Group membership & 0.043 & 0.045 \\
\hline Type of project of specialisation & 0.028 & -0.032 \\
\hline \multicolumn{3}{|l|}{ Functions at Centroids } \\
\hline Group 1 & 0.828 & 1.432 \\
\hline Group 2 & -1.415 & -0.702 \\
\hline Group 3 & 4.295 & -2.615 \\
\hline
\end{tabular}

It can be deduced from Table 6 that Function 1 separates Group 3 from the rest. Group 3 has the highest centroid in Function 1. In Function 1, technology use has the highest loading along with construction industry work experience, age of owner and firm experience. Table 7 shows that the Group 3 firms have higher overall performance on the characteristics than the rest of the groups. Although the Group 3 firms are made of younger firm owners (mean age $=52.22$ ) compared to those of Group 1 (mean age = 53.05), they make more use of technology and are marginally more experienced than those of group 1. The Group 3 firms can be regarded as the top class ICFs. Function 2 relates more with Group 1. Technology use, construction 
industry work experience, age of owner and firm registration with client bodies are the variables that underpin Function 2. Table 7 indicates that the Group 1 firms are the next in terms of performance on the characteristics. The firms in this group have a lower firm experience, but are registered with more client bodies than those of Group 3, perhaps, in the quest for jobs to keep surviving. They are also more conservative on the use of technology. Group 1 firms are christened middle class ICFs. The Group 2 ICFs are low class. Table 6 shows that they have low centroids in both Functions 1 and 2. In Table 7, it can be seen that the group is made up of much younger (mean age $=40.94$ ) relatively inexperienced firm owners whose firms are yet to register with most client bodies in their area of operations.

Table 7. Means of Variables in Each Cluster

\begin{tabular}{|c|c|c|c|c|c|c|}
\hline \multirow[t]{2}{*}{ Variables } & \multicolumn{2}{|c|}{$\begin{array}{l}\text { Group } 1 \\
\mathrm{n}=172\end{array}$} & \multicolumn{2}{|c|}{$\begin{array}{c}\text { Group } 2 \\
n=213\end{array}$} & \multicolumn{2}{|c|}{$\begin{array}{c}\text { Group } 3 \\
n=37\end{array}$} \\
\hline & Mean & SD & Mean & SD & Mean & SD \\
\hline Age of owner & 53.05 & 6.23 & 40.94 & 6.34 & 52.22 & 7.00 \\
\hline Education of owner & 1.24 & 0.53 & 1.24 & 0.55 & 1.46 & 0.51 \\
\hline Marital status & 2.83 & 0.50 & 3.16 & 0.49 & 2.70 & 0.66 \\
\hline Professional qualification & 2.78 & 1.33 & 2.47 & 1.32 & 2.08 & 1.61 \\
\hline $\begin{array}{l}\text { Construction industry work } \\
\text { experience }\end{array}$ & 16.19 & 4.73 & 6.70 & 3.95 & 16.95 & 7.47 \\
\hline Gender & 0.91 & 0.28 & 0.84 & 0.37 & 0.86 & 0.35 \\
\hline Previous self-employment & 0.19 & 0.39 & 0.14 & 0.34 & 0.49 & 0.51 \\
\hline Ethnicity of owner & 0.81 & 0.39 & 0.88 & 0.33 & 0.76 & 0.43 \\
\hline $\begin{array}{l}\text { Ownership of other } \\
\text { business(es) }\end{array}$ & 0.30 & 0.46 & 0.12 & 0.33 & 0.16 & 0.37 \\
\hline CEO duality & 0.81 & 0.39 & 0.92 & 0.26 & 0.86 & 0.35 \\
\hline Technology use & $18,332.55$ & $8,809.85$ & $13,357.09$ & $8,426.26$ & $66,637.84$ & $19,819.19$ \\
\hline Firm location & 0.79 & 0.41 & 0.85 & 0.35 & 0.95 & 0.23 \\
\hline $\begin{array}{l}\text { Type of project of } \\
\text { specialisation }\end{array}$ & 0.87 & 0.33 & 0.87 & 0.33 & 0.95 & 0.23 \\
\hline Firm experience & 15.94 & 9.06 & 7.74 & 4.68 & 17.99 & 6.83 \\
\hline $\begin{array}{l}\text { Firm registration with client } \\
\text { bodies }\end{array}$ & 3.36 & 1.23 & 2.32 & 0.90 & 2.46 & 0.84 \\
\hline $\begin{array}{l}\text { Annual turnover ( } \times \text { NGN } \\
100,000,000)\end{array}$ & 2.04 & 0.36 & 1.99 & 0.61 & 1.95 & 0.33 \\
\hline Group membership & 0.15 & 0.35 & 0.08 & 0.28 & 0.14 & 0.35 \\
\hline $\begin{array}{l}\text { Founding condition/initial } \\
\text { size }\end{array}$ & 2.68 & 1.76 & 1.94 & 1.12 & 2.46 & 1.64 \\
\hline Organisational structure & 0.90 & 0.31 & 0.78 & 0.42 & 0.84 & 0.37 \\
\hline Level of firm registration & 0.99 & 0.96 & 1.37 & 1.09 & 1.95 & 0.91 \\
\hline Mean & 921.97 & & 671.62 & & $3,337.30$ & \\
\hline
\end{tabular}

Note: $\mathrm{SD}=$ Standard deviation 
Apparently, a major departure of this study from previous grouping systems is that annual turnover did not load significantly under any of the functions. Its loadings were 0.002 and 0.049 under Functions 1 and 2 respectively. Similarly, it had close mean values across the three groups (NGN 204 million, NGN 199 million and NGN 195 million for Groups 1, 2 and 3 respectively). This result is indicative of a high level of competitiveness among ICFs in the research area. It showed that disparities in levels of annual turnover within the indigenous construction firm group is fast disappearing as a result of the level playing ground for construction firms enshrined by the Nigerian procurement reforms. Akintoye and Skitmore (1991) similarly found no difference in the level of profitability of construction firms, which they said was as a result of competition. BPP (2015) showed that most ICFs are classified under Category $E$, which is corroborated by the finding of this study that annual turnover is a poor discriminant of ICFs in the study area.

\section{DISCUSSION OF FINDINGS}

In this study, $97.9 \%$ of the firms were correctly classified as top, middle or low class ICFs. This classification is similar to the small, medium and large-firm classification which already exists, but does not support the 5-level classification used by the BPP (2015) and Almutairi (2017). It also closely mirrors the classification of ICFs into low, average and high performer firms by Ogbu (2017). It should be emphasised, however, that the classifications are tailored to different purposes. Apparently, the approaches to contractor classification will continue to differ based on the intentions of the practitioner. In this case, the classification was intended to create groups that will make contractor development programmes easier to administer. A particular significance of the present classification is that it broadened the variables used and adopted an unsupervised statistical approach. The approach demonstrated in this paper may be adopted by government agencies in objectively classifying their shortlisted ICFs.

The most important criteria for classifying ICFs are technology use, construction industry work experience of the owner, age of the owner, firm experience and firm registration with client bodies.

Egesa (2011) identified use of technology and firm age as important determinants of survival of indigenous Ugandan firms. Stobaugh and Telesio (1983) hypothesised the existence of technology driven firms. Prominence of technology use as an important grouping variable for ICFs suggests the validity of the conclusions of these two previous studies. Although neither of the two studies was focused solely on the construction industry, the results of this study evidently suggest the spread and uptake of technology (as measured by financial commitment to information and communications technology) by ICFs.

The findings of this study also emphasise construction industry work experience of the firm owners as being critical in grouping the firms. Industry-based experience is often an important criterion in the employment of staff of construction firms. Also, many researchers consider it an important variable in distinguishing the characteristics of their respondents (cf. Jeong, 1998; Lyons and Skitmore, 2004; Azhar, Farooqui and Ahmed, 2008). Construction is a project-oriented industry and projects are too often dissimilar. A wide experience means that a practitioner has been exposed to numerous project situations such that individual exposures have added up to develop in the person the acumen of innovative thinking that 
is associated with success in project execution (Dubois and Gadde, 2002). Besides success at the project level, Madhoushi and Ghaedi (2013) also posited that a firm owner's experience is critical to the firm's survival. These connections between project and firm performances and a firm owner's experience aided the emergence of this variable as being important to the grouping of firms in this study.

Firm experience, which is different from firm owner's experience is equally important in the grouping of firms. Plebankiewicz (2010) ranked firm experience as one of the most important prequalification criteria of Polish contractors. This study measured firm experience based on the types of projects with which a firm has been involved, for example, whether the firm was the main or subcontractor in an international, federal, state or local government project. A firm that was experienced in an international project as a main contractor was considered more experienced than one that is experienced in a federal government project as a main contractor. Such a firm will more likely possess the entrepreneurial skills canvassed by Ofori (1991) and Kubayi (2014). The discriminant analysis showed that Function 1 (Experience) is particularly distinguishable from Function 2 (Marketing) by the high loading of firm experience and low loading of registration with client bodies. It is apparent that the experienced firms have reduced marketing activities, while the firms with low experience struggle to gain a higher market share by registering with many client bodies.

\section{CONCLUSIONS}

A statistical classification of ICFs in south-south Nigeria was undertaken in this study to explore how the firms may be grouped for contractor development programme purposes. Three groups of firms emerged from the analysis - top class, middle class and low class - indigenous contractors. Discriminant analysis showed that two functions were responsible for this grouping and that those two functions are particularly distinguishable by firm experience (which represents Function 1) and registration with client bodies which distinguishes Function 2. On account of the distinguishing variables, the functions were christened the experience and the marketing functions respectively.

An important implication of the findings of this study for policymaking is that it is inadequate to simply group ICFs using the grading system of the BPP in Nigeria. The underlying constructs discovered in this study should be considered in such classifications, which preferably should be based on the unsupervised grouping using the approach of cluster analysis demonstrated in this study.

For researchers, the findings of this study imply that simply grouping firms based on some non-statistically derived criteria is inadequate and may ignore serious discriminating constructs among the set of firms. If construction firms are to be grouped and treated differently in a study, a statistically based classification should first be carried out to obtain an unbiased grouping of the firms. To expand their experiences, ICFs should seek to participate in projects with more critical clients.

Further similar studies can be conducted using the databased of the BPP and for other geopolitical zones of the country as well. Such studies should provide models for predicting the group to which a firm belongs which will also aid contractor selection. 


\section{REFERENCES}

Adams, O. (1997). Contractor development in Nigeria: Perceptions of contractors and professionals. Construction Management and Economics, 15(1): 95-108. https://doi.org/10.1080/014461997373141.

Adeyemi, A.Y., Ojo, S.O., Aina, O.O. and Olanipekun, E.A. (2006). Empirical evidence of women under-representation in the construction industry in Nigeria. Women in Management Review, 21(7): 567-577. https://doi. org/10.1108/09649420610692516.

Adeyemi, A.Y., Oladapo, A.A. and Akindele, O. (2005). Balancing globalisation, glocalisation and sustainable development equation in the construction industry in Nigeria. Paper presented at the 3rd Postgraduate Conference 2005 Construction Industry Development. Johannesburg, South Africa, 9-11 October.

Akintoye, A., Mclntosh, G. and Fitzgerald, E. (2000). A survey of supply chain collaboration and management in the UK construction industry. European Journal of Purchasing and Supply Management, 6(3-4): 159-168. https://doi. org/10.1016/S0969-7012(00)00012-5.

Akintoye, A. and Skitmore, M. (1991). Profitability of UK construction contractors. Construction Management and Economics, 9(4): 311-325. https://doi. org/10.1080/01446199100000025.

Almutairi, S. (2017). Assessment and development of the Saudi's contractors classification system. PhD diss. Arizona University.

Amaratunga, D., Baldry, D., Sarshar, M. and Newton, R. (2002). Quantitative and qualitative research in the built environment: Application of "mixed" research approach. Work Study, 51(1): 17-31. https://doi. org/10.1108/00438020210415488.

Azhar, N., Farooqui, R.U. and Ahmed, S.M. (2008). Cost overrun factors in construction industry of Pakistan. Proceedings: First International Conference on Construction in Developing Countries (ICCIDC-I), Advancing and Integrating Construction Education, Research and Practice. Karachi: ICCDC-I, 499-508.

Birley, S. (1987). Female entrepreneurs: Are they really any different? Available at: https://dspace.lib.cranfield.ac.uk/bitstream/handle/1826/439/SWP0587. pdf? sequence=2.

Bian, H. (n.d.). SPSS discriminant function analysis. Available at: http://kharazmistatistics.ir/Uploads/Public/MY\%20article/SPSS\%20Discriminant\%20 Function\%20Analysis.pdf.

Bureau of Public Procurement (BPP) (2015). Contractors, consultants and service providers categorised and classified on national database. Available at: http://www.bpp.gov.ng/index.php?option=com_joomdoc\&task= document.download\&path=list-of-classified-companies-on-nationaldatabase-1 st-batch\&ltemid=845.

Choudhry, R.M., Fang, D. and Lingard, H. (2009). Measuring safety climate of a construction company. Journal of Construction Engineering and Management, 135(9): 890-899. https://doi.org/10.1061/(ASCE)CO.19437862.0000063.

Dainty, A.R., Bagilhole, B.M. and Neale, R.H. (2000). A grounded theory of women's career under-achievement in large UK construction companies. Construction Management and Economics, 18(2): 239-250. 
Dikmen, I., Birgonul, M.T. and Budayan, C. (2009). Strategic group analysis in the construction industry. Journal of Construction Engineering and Management, 135(4): 288-297. https://doi.org/10.1061/(ASCE)0733-9364(2009) 135:4(288).

Dlungwana, W.S. and Rwelamila, P.D. (2004). Contractor development models that meet the challenges of globalization: A case for developing management capability of local contractors. Available at: http://researchspace.csir.co.za/ dspace/bitstream/10204/1936/1/Dlungwana_2004.pdf.

Dubois, A. and Gadde, L.E. (2002). The construction industry as a loosely coupled system:Implicationsforproductivityandinnovation.ConstructionManagement and Economics, 20(7): 621-631. https://doi.org/10.1080/01446190210163543.

Dulaimi, M.F. and Shan, H.G. (2002). The factors influencing bid mark-up decisions of large-and medium-size contractors in Singapore. Construction Management and Economics, 20(7): 601-610. https://doi.org/10.1080/01446190210159890.

Drew, D.S. and Skitmore, M.R. (1990). Analysing bidding performance: Measuring the influence of contract size and type. In V. Ireland and D. Cheetham (eds.), Proceedings of the International Council for Building Research Studies and Documentation, CIB W-55/65. Sydney: International Council for Building (CIB), 129-139.

Egesa, K.A. (2011). Indigenous firms' survival in Uganda: Is there a role for increased technology use? The Bank of Uganda Journal, 4(1): 81-108.

Gaith, F.H., Khalim, A.R. and Ismail, A. (2012). Application and efficacy of information technology in construction industry. Scientific Research and Essays, 7(38): 3223-3242. https://doi.org/10.5897/SRE1 1.955.

Hatush, Z. and Skitmore, M. (1997). Evaluating contractor prequalification data: Selection criteria and project success factors. Construction Management and Economics, 15(2): 129-147. https://doi.org/10.1080/01446199700000002.

Holt, G.D. (1996). Applying cluster analysis to construction contractor classification. Building and Environment, 31(6): 557-568. https://doi.org/10.1016/03601323(96)00028-5.

Hollingshead, A.B. (1975). Four factor index of social status. Unpublished working paper. Yale University. Available at: https://sociology.yale.edu/sites/default/ files/files/yjs_fall_2011.pdf\#page=21.

Idoro, G.I. (2011). Comparing occupational health and safety (OHS) management efforts and performance of Nigerian construction contractors. Journal of Construction in Developing Countries, 16(2): 151-173.

Jeong, B.Y. (1998). Occupational deaths and injuries in the construction industry. Applied Ergonomics, 29(5): 355-360. https://doi.org/10.1016/S00036870(97)00077-X.

Kalleberg, A.L. and Leicht, K.T. (1991). Gender and organizational performance: Determinants of small business survival and success. Academy of Management Journal, 34(1): 136-161. https://doi.org/10.2307/256305. https://doi.org/10.2307/256305.

Kartam, N.A., Flood, I. and Koushki, P. (2000). Construction safety in Kuwait: Issues, procedures, problems and recommendations. Safety Science, 36(3): 163184. https://doi.org/10.1016/S0925-7535(00)00041-2.

Korenman, S. and Neumark, D. (1991). Does marriage really make men more productive? Journal of Human Resources, 26(2): 282-307. https://doi. org/10.2307/145924. 
Kubayi, S. (2014). Contractor development through Vuk'uphile Learnership Programme in the Eastern Cape Department of Roads and Public Works. MMgt diss. University of Witwatersrand.

Loosemore, M. and Waters, T. (2004). Gender differences in occupational stress among professionals in the construction industry. Journal of Management in Engineering, 20(3): 126-132. https://doi.org/10.1061/(ASCE)0742$597 \times(2004) 20: 3(126)$.

Lyons, T. and Skitmore, M. (2004). Project risk management in the Queensland engineering construction industry: A survey. International Journal of Project Management, 22(1): 51-61. https://doi.org/10.1016/S0263-7863(03)00005-X.

Madhoushi, M. and Ghaedi, M. (2013). Founder's characteristics and firm survival: Iranian study. World Applied Programming, 3(10): 504-51 1.

McCutcheon, R.T. (2001). An introduction to employment creation in development and lessons learnt from employment creation in construction. Paper presented at the WORK200 1 First International Conference on Employment Creation in Development. Johannesburg, South Africa, 2-5 April.

Miller, J.G. and Roth, A.V. (1994). A taxonomy of manufacturing strategies. Management Science, 40(3): 285-304. https://doi.org/10.1287/mnsc.40.3.285.

Odeyinka, H.A. (2000). An evaluation of the use of insurance in managing construction risks. Construction Management and Economics, 18(5): 519-524. https://doi.org/10.1080/014461900407329.

Ofori, G. (2000). Challenges of construction industries in developing countries: Lessons from various countries. Paper presented at the 2 nd International Conference on Construction in Developing Countries: Challenges Facing the Construction Industry in Developing Countries. Gaborone, November.

(1991). Programmes for improving the performance of contracting firms in developing countries: A review of approaches and appropriate options. Construction Management and Economics, 9(1): 19-38. https://doi. org/10.1080/01446199100000003.

Ogbu, C.P. (2018). Survival practices of ICFs in Nigeria. International Journal of Construction Management, 18(1): 78-91. https://doi.org/10.1080/15623599.2 016.1277056.

. (2017). Marketing strategies and performance of ICFs in Nigeria. Journal of Construction in Developing Countries, 22(1): 1-19. https://doi.org/10.21315/ jcdc2017.22.1.1.

Patton, M.Q. (1990). Qualitative Evaluation and Research Methods. Beverly Hills, CA: Publications Inc., 169-186.

Pizzoli, E. and Palmegiani, G. (2007). Rural Development Statistics (RDS) for Policy Monitoring: A Rural-Urban Territorial Classification and Farmers' Income Data. Alger, Algeria: African Commission on Agricultural Statistics (AFCAS). Available at: www.fao.org/es/ess/meetings.

Plebankiewicz, E. (2010). Construction contractor prequalification from Polish clients' perspective. Journal of Civil Engineering and Management, 16(1): 57-64. https://doi.org/10.3846/jcem.2010.05.

Stobaugh, R. and Telesio, P. (1983). Match manufacturing policies and product strategy. Harvard Business Review, 61 (2): 113-120.

Tran, H. and Carmichael, D.G. (2013). A contractor's classification of owner payment practices. Engineering, Construction and Architectural Management, 20(1): 29-45. https://doi.org/10.1108/09699981311288664. 
Wang, C.M., XU, B.B., Zhang, S.J. and Chen, Y.Q. (2016). Influence of personality and risk propensity on risk perception of Chinese construction project managers. International Journal of Project Management, 34(7): 1294-1304. https://doi. org/10.1016/j.ijproman.2016.07.004.

Woldie, A. and Adersua, A. (2004). Female entrepreneurs in a transitional economy: Businesswomen in Nigeria. International Journal of Social Economics, 31 (1/2): 78-93. https://doi.org/10.1108/03068290410515439.

Wong, Y.C. (1986). Entrepreneurship, marriage and earnings. The Review of Economics and Statistics, 68(4): 693-699. https://doi.org/10.2307/1924531. 